\title{
THE IMPACT OF CLIMATIC FACTORS ON THE PERCENTAGE OF THE YOUNG IN THE POPULATION OF BROWN HARE (Lepus europaeus P.) IN VOJVODINA
}

\author{
Miloš Beuković ${ }^{1}$ Zoran Popović ${ }^{2}$, Vladimir Maletić ${ }^{3}$, Dejan Beuković ${ }^{1}$, Dara Đaković ${ }^{4}$ \\ ${ }^{1}$ Poljoprivredni fakultet Novi Sad, Univerzitet u Novom Sadu, \\ Trg Dositeja Obradovica 8, 21000, Novi Sad \\ ${ }^{2}$ Poljoprivredni fakultet Zemun, Univerzitet u Beogradu, \\ Nemanjina 6, 11080, Beograd-Zemun \\ ${ }^{3}$ Šumarski fakultet Skoplje, Univerzitet „, Sv. Kiril i Metodij“ vo Skopje, \\ Blvd. Aleksandar Makedonski bb, 1000 Skopje, Republic of Macedonia \\ ${ }^{4}$ Lovački savez Vojvodine, Jovana Đorđevića, 21000 Novi Sad, \\ beukovic@polj.ns.ac.yu // zpopovic@agrifaculty.bg. ac.yu // beuk@polj.ns.ac.yu // hunters@eunet.yu.
}

In order to study the influence of climatic factors on the participation of the young in the population of brown hare in Vojvodina, in the period from 1993 to 2008 data have been processed for the average monthly temperature and rainfall by month of brown hare reproductive activity (March-August) on the \% of participation of the young in the population. The average number of brown hare in Vojvodina in the mentioned period was 261,216, with expressive cycle. The minimum number of 204,528 brown was recorded in 2001, and the largest in 1995-326,901. At the same period the average yearly shooting was 41,115 specimens, most shoots were made in $1994-65,848$ specimens, while the smallest shooting was recorded in $2002-25,753$ brown hare. In order to test the age of the rabbit on the basis of eye lenses weight and determining the \% of the young processed a total of 133,545 eye lenses for 16 years, with yearly average of 8,346 eye lenses. The average percentage of the young brown hare in the observed period was $60 \%$, which is very good. The average percentage of the young shows cycle depending on climatic factors. The highest \% of young brown hare was established in 1994 and was $70 \%$, while the lowest \% of the young was in $2006-$ $50 \%$. On the basis of regression analysis there has been found a small dependence on $\%$ of the young brown hare on the temperature and precipitation in the reproduction period from March to August for the last 16 years which is not statistically significant.

Key words: Vojvodina; brown hare; temperature; rainfall; percent of the young

\section{ВЛИЈАНИЕ НА КЛИМАТСКИТЕ ФАКТОРИ ВРЗ ПРОЦЕНТОТ НА МЛАДИТЕ ВО ПОПУЛАЦИЈАТА НА КАФЕАВИТЕ ЗАЈАЦИ (Lepus europaeus Р.) ВО ВОЈВОДИНА}

Со цел да се истражи влијанието на климатските фактори врз учеството на младите во популацијата на зајаците во Војводина, во периодот од 1993 до 2008 година се обработени податоците за просечните месечни температури на воздухот и количеството на врнежите во месеците на репродуктивна активност на зајаците (март-август) и нивното влијание врз процентот на учеството на младите во популацијата. Просечниот број на зајаци во Војводина во наведениот период изнесуваше 261.216 единки, со изразена цикличност. Најмал број од 204.528 примероци е регистриран во 2001 година, а најголем од 326.901 во 1995 година. Во истиот период се отстрелани вкупно 620.027 зајаци, односно просечно годишно 41.115. Најголем отстрел од 65.848 примероци е забележан во 1994 година, а најмал во 2002 година, кога се отстрелани вкупно 25.753 зајаци. За испитување на возраста на зајаците врз основа на масата на очната леќа и утврдување на процентот на млади, обработени се вкупно 133.545 очни леќи за 16 години, односно просечно годишно 8.346. Утврдениот просечен процент на млади во вкупната популација беше многу добар и изнесуваше 60 \%, а утврдена е неговата цикличност во зависност од климатските фактори. Најголем процент на млади зајаци е утврден во 1994 година и изнесуваше $70 \%$, а најмал од само $50 \%$ е констатиран во 2006 година. Со регресиона анализа е утврдена слаба зависност на процентот на млади зајаци во вкупната популација од просечните месечни температури на воздухот и од просечното месечно количество на врнежи, која не е статистички значајна.

Клучни зборови: Војводина; зајак; температура; врнежи; процент на млади 


\section{INTRODUCTION}

Brown hare (Lepus europaeus Pall.) is one of the most widespread and most hunted quarry in Europe. In Serbia the best habitat for the brown hare are plain areas, especially in Vojvodina. The intensification of agriculture changed the typical habitat for the brown hare, especially a drastic increase in the area under arable crops, which are intensively treated with pesticides, and at the same time, reduced the area under fodder (Beuković and Marinković, 1997).

On the basis of the researches on the brown hare population in Vojvodina (Jovanović and Aleksić 1976) there has been found that the first litter is in early March, the second in April, the third in late May and early June, the fourth in July and the fifth at the end of August. From these five litters the first and the fifth ones are the least, while the third and fourth ones are with the highest number of the young. The research about the influence of meteorological elements on the grown warren in Vojvodina (Jovanović et al. 1971) during the three years from 1968 to 1970 for the period from February to May indicates "that there is a certain legal connection between the movement of only secondary monthly air temperature in May and the percentage of the brown hare, while this is not the case with other months". These authors in the same research have found that between the amount of precipitation and growth of brown hare "there is no a proper relationship".

The recent research (Popović et al. 1997) on the impact on average monthly temperature and the amount of monthly precipitation in the $\%$ of the young in the brown hare population in Vojvodina during the period from March to August from 1974 to 1992 points to the relationship between monthly temperature and the percentage of the young brown hare, that statistically is not significant. These authors also found that increasing the monthly precipitation reduces the participation of the young brown hare and that the dependence is on the border of significance.

The rational usage of the brown hare population and micro-population is one of the most important forms of protection in the brown hare deteriorated environmental conditions, and is fully and exclusively in the hands of hunters. More than 40 years, on all hunting grounds in Vojvodina during the hunting season the eyes of shooting the brown hare (one from each) have been collected, after which the processing of samples by pre-established procedure has taken place. On the basis of these investigations and the criteria (Šelmić, 1980) and on the basis of the Spring state of brown hare number and information about shooting from the previous year, the state of micropopulation of brown hare is established and on the basis of that, recommendations are given for users of the hunting ground on possible audit for the shooting plans.

The aim of this research is to determine the influence of climatic factors, i.e. the average monthly temperature and average monthly amount of precipitation in the $\%$ of young population in the rabbit warren in Vojvodina for the last 16 years.

\section{MATERIAL AND METHODS}

In order to study the influence of climatic factors on the percentage of the young in population of the brown hare in Vojvodina on the total area of $1,985,626$ ha in the period from 1993 to 20,008 the data have been processed for the number of specimens in spring, the total shooting, $\%$ of the young brown hare, data on average monthly temperature and rainfall in the reproductive activities of the brown hare from March to August .

Data about climatic factors are taken from 4 meteorological stations such as Rimski Šančevi, Palić, Banatski Karlovac and Sremska Mitrovica, published in the meteorological yearbook of the Hydro-meteorological Institute of the Republic of Serbia. Data of the number, shooting $\%$ of the young brown hare population in Vojvodina are taken from the records of the Hunting Association of Vojvodina, which continuously examines the $\%$ of the young on the basis of determining the age depending on eye lenses weight.

For data processing the procedure of linear regression and correlation was applied.

\section{THE RESULTS OF THE RESEARCH AND DISCUSSION}

According to the data in $1^{\text {st }}$ Chart, the population of the brown hare in Vojvodina is stable with an expressive cycle. The average number for the observed period of 16 years is 261,216 brown hare. The largest number of the brown hare population in Vojvodina was recorded in 1995, and the 
number was 326,901 , while the lowest number was recorded in 2001 of only 204,528.

The average annual shooting of the brown hare in Vojvodina, observed for a period of 16 years amounted to 41,115 specimens. The highest shooting was recorded in 1994, 65,848 specimens while the smallest shooting was in 2002, only 25,753 of the brown hare (Chart 1).

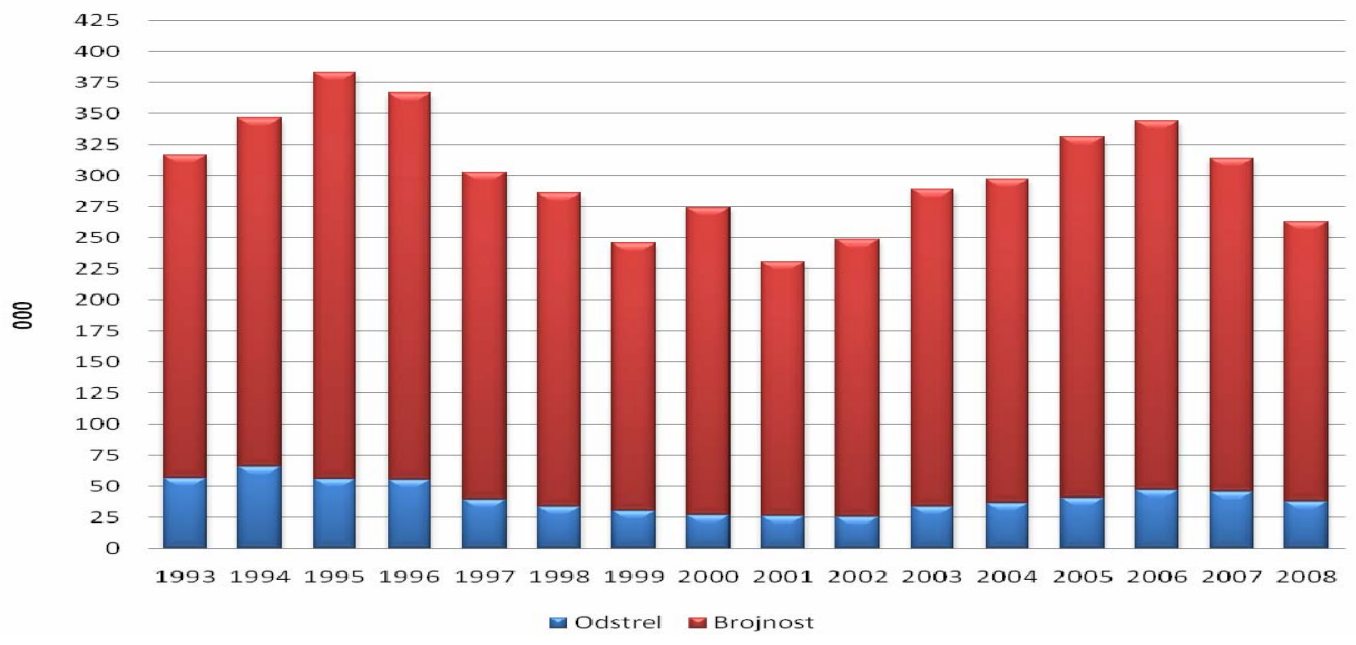

Chart 1. Number of the shot brown hare in Vojvodina

Table 1

Number of samples and reviewed eyes and \% of the young brown hare in Vojvodina by years

\begin{tabular}{ccccc}
\hline \hline Year & Number of samples & Reviewed eyes & \% young & Assessment \% young \\
\hline 1993 & $\mathbf{1 7 3}$ & $\mathbf{6 . 0 5 3}$ & 69 & Excellent \\
1994 & 216 & 8.709 & $\mathbf{7 0}$ & Excellent \\
1995 & 203 & 7.900 & 62 & Very good \\
1996 & 267 & 7.299 & 65 & Excellent \\
1997 & 236 & 7.341 & 62 & Very good \\
1998 & 240 & 7.658 & 54 & Good \\
1999 & 226 & 7.139 & 62 & Very good \\
2000 & 244 & 8.656 & 54 & Good \\
2001 & 264 & 8.581 & 61 & Very good \\
2002 & 242 & 8.482 & 59 & Very good \\
2003 & 269 & 8.691 & 55 & Good \\
2004 & 260 & 8.235 & 59 & Very good \\
2005 & 287 & 9.301 & 62 & Very good \\
2006 & $\mathbf{2 9 6}$ & $\mathbf{1 0 . 0 2 9}$ & $\mathbf{5 0}$ & Bad \\
2007 & 268 & 9.459 & 55 & Very good \\
2008 & 295 & 10.020 & 54 & Good \\
Average & $\mathbf{2 4 9}$ & $\mathbf{8 . 3 4 6}$ & $\mathbf{6 0}$ & Very good \\
\hline \hline
\end{tabular}

According to the data in Table 1 it can be seen that the average number of samples submitted to testing, for the previous period of 16 years, was 249. Most samples of eye lenses were delivered in
2006 - a total of 296, while the least of the samples was submitted in 1993 - 173 samples.

The total number of submitted eye lens for the age analysis, during 16 years, was 133,536 , 
which is on average 8,346 of eye lenses per year. Most of the eye lenses for analysis were delivered in $2006-10,029$ eyes, and least has been delivered in 1993 - just 6,053 .

On the basis of investigations conducted in the laboratory of the Hunting Association of Voj- vodina according to the data in Table 1 and Chart 2 it can be seen that the average percentage of the young warren, observed in 16 years, was $60 \%$, which is a very good rating. The worst of the young brown hare was recorded in 2006 - only 50 $\%$ and the best of it was in 1994 with $70 \%$.

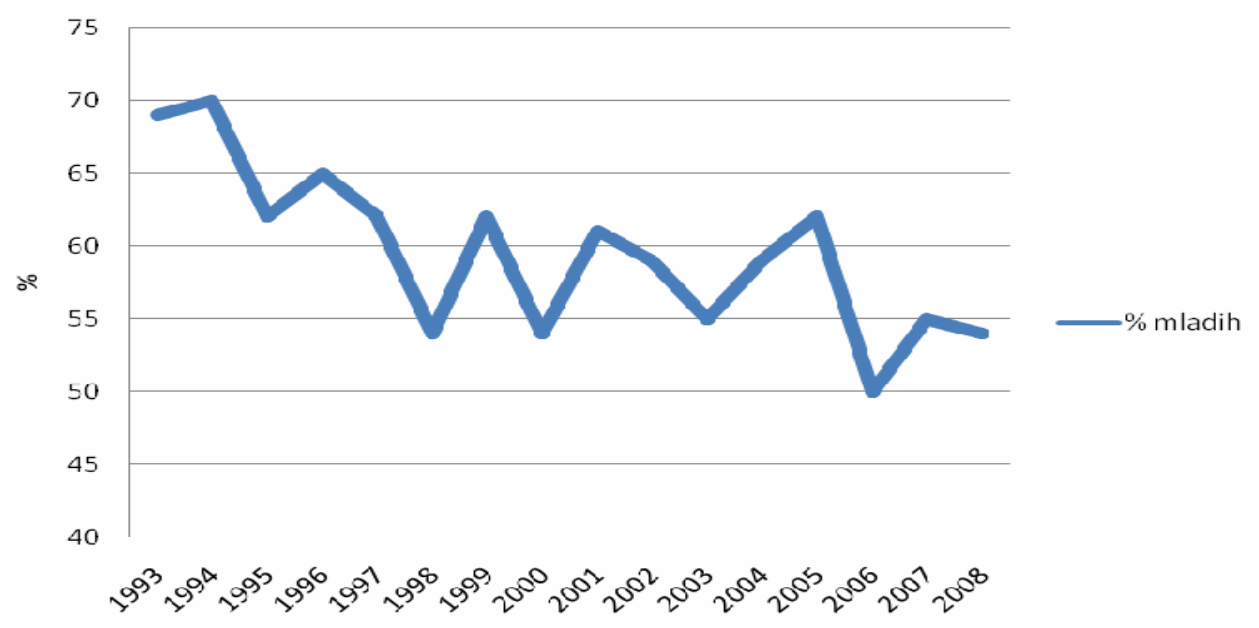

Chart 2. Percentage of the young by years

Table 2

Average monthly temperature and rainfall from March to August for 4 years by the Hydrological stations in Vojvodina

\begin{tabular}{|c|c|c|c|c|c|c|c|c|c|c|c|c|c|c|}
\hline \multirow[t]{2}{*}{ Year } & \multicolumn{2}{|c|}{ March } & \multicolumn{2}{|c|}{ April } & \multicolumn{2}{|c|}{ May } & \multicolumn{2}{|c|}{ Jun } & \multicolumn{2}{|c|}{ July } & \multicolumn{2}{|c|}{ August } & \multicolumn{2}{|c|}{ Average } \\
\hline & C & $\mathrm{ml}$ & C & $\mathrm{ml}$ & C & $\mathrm{ml}$ & C & $\mathrm{ml}$ & C & $\mathrm{ml}$ & $\mathrm{C}$ & $\mathrm{ml}$ & C & $\mathrm{ml}$ \\
\hline 1993 & 3.9 & 49.4 & 11.2 & 38.1 & 17.8 & 20.0 & 20.1 & 42.8 & 21.1 & 34.5 & 21.9 & 50.1 & 16.0 & 39.1 \\
\hline 1994 & 8.8 & 28.2 & 11.7 & 53.4 & 17.2 & 40.5 & 20.2 & 91.1 & 23.4 & 48.3 & 22.7 & 52.6 & 17.3 & 52.4 \\
\hline 1995 & 5.8 & 32.2 & 11.3 & 44.8 & 16.0 & 61.9 & 19.3 & 129.7 & 23.5 & 35.8 & 20.6 & 63.4 & 16.1 & 61.3 \\
\hline 1996 & 2.2 & 28.9 & 11.6 & 33.0 & 18.4 & 69.1 & 20.8 & 57.2 & 20.2 & 57.5 & 20.8 & 80.7 & 15.7 & 54.4 \\
\hline 1997 & 5.3 & 18.6 & 7.6 & 69.9 & 17.6 & 33.3 & 20.8 & 58.4 & 20.3 & 104.0 & 20.4 & 78.4 & 15.3 & 60.4 \\
\hline 1998 & 4.0 & 18.2 & 13.0 & 35.8 & 16.1 & 63.7 & 21.8 & 81.9 & 21.9 & 97.8 & 21.8 & 59.5 & 16.4 & 59.5 \\
\hline 1999 & 7.8 & 16.4 & 12.7 & 54.8 & 16.9 & 67.1 & 20.2 & 103.1 & 21.6 & 183.6 & 21.4 & 40.7 & 16.8 & 77.6 \\
\hline 2000 & 6.5 & 33.8 & 14.9 & 32.3 & 18.7 & 31.1 & 22.0 & 18.8 & 22.1 & 25.7 & 24.2 & 7.4 & 18.0 & 24.8 \\
\hline 2001 & 9.9 & 68.6 & 11.0 & 110.0 & 18.0 & 66.2 & 18.3 & 221.3 & 22.1 & 51.3 & 22.7 & 37.0 & 17.0 & 92.4 \\
\hline 2002 & 8.6 & 12.6 & 11.3 & 27.7 & 19.3 & 68.9 & 22.1 & 48.8 & 23.4 & 60.1 & 21.6 & 58.5 & 17.7 & 46.1 \\
\hline 2003 & 5.4 & 6.2 & 11.0 & 15.8 & 20.6 & 28.8 & 23.9 & 33.5 & 22.4 & 67.9 & 24.0 & 31.2 & 17.9 & 30.6 \\
\hline 2004 & 6.3 & 20.7 & 12.2 & 87.1 & 15.2 & 69.9 & 19.8 & 82.3 & 22.0 & 89.1 & 21.2 & 62.7 & 16.1 & 68.6 \\
\hline 2005 & 4.1 & 51.4 & 11.5 & 53.3 & 17.2 & 53.4 & 19.5 & 97.9 & 21.5 & 89.8 & 19.9 & 130.1 & 15.6 & 79.3 \\
\hline 2006 & 5.4 & 55.6 & 12.7 & 88.7 & 16.5 & 49.8 & 19.7 & 98.2 & 23.4 & 38.6 & 20.3 & 115.7 & 16.3 & 74.4 \\
\hline 2007 & 8.7 & 74.2 & 13.3 & 1.2 & 18.5 & 89.2 & 22.3 & 76.4 & 23.4 & 28.1 & 22.8 & 52.4 & 18.1 & 53.6 \\
\hline 2008 & 7.6 & 55.6 & 12.7 & 45.4 & 18.1 & 46.4 & 21.7 & 103.6 & 21.8 & 50.6 & 22.8 & 22.7 & 17.3 & 54.1 \\
\hline Avg. & 6.2 & 35.7 & 11.8 & 49.5 & 17.6 & 53.7 & 20.8 & 84.0 & 22.1 & 66.4 & 21.8 & 58.9 & & \\
\hline
\end{tabular}


Analyzing the data, the value of the correlation coefficient $(r=-0.3846)$ between average monthly temperature and participation of the young in the population of the brown hare, talks about the low and negative dependence on the meteorological factors to the $\%$ of the young in the reproduction period.

Regression analysis revealed that there is a linear dependence on the \% of the young, compared to the average monthly temperature in the reproduction period. The linear regression coefficient $(b=-2.3802)$ with a negative mark reflects a mild trend of reducing $\%$ of the young brown hare by increasing the average monthly temperature.

The effect of temperature during the reproduction period to the $\%$ of the young brown hare is not statistically significant.
The value of the coefficient of correlation between the amount of monthly precipitation and \% of the young is small and positive $(r=0.0613)$, which talks about the low dependence on the meteorological factors in the $\%$ of the young in the reproduction period.

Regression analysis revealed a linear relationship between the average amount of monthly precipitation in the period of reproduction and \% of young in the brown hare population. The linear regression coefficient $(b=0.0193)$ with a positive mark shows a mild trend of increasing \% of the young by increasing the average amount of monthly precipitation.

The influence of precipitation during the period of reproduction of the young is not statistically significant.

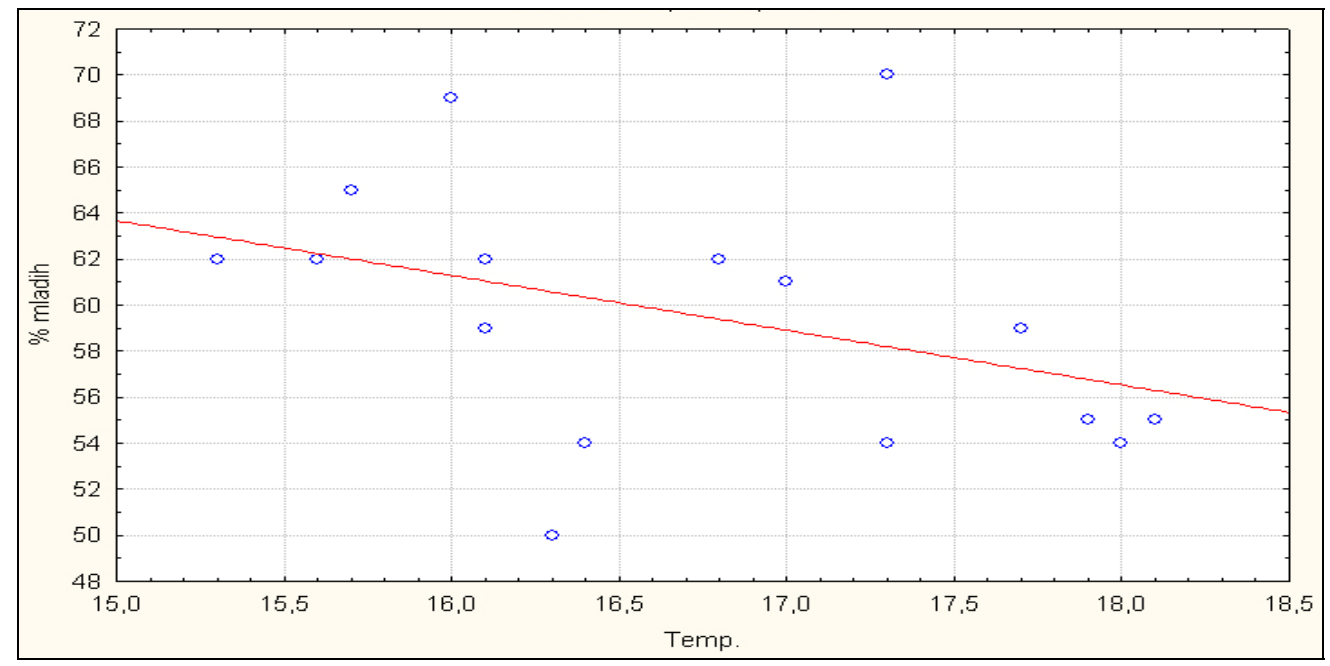

Chart 3. The effect of temperature on the $\%$ of the young

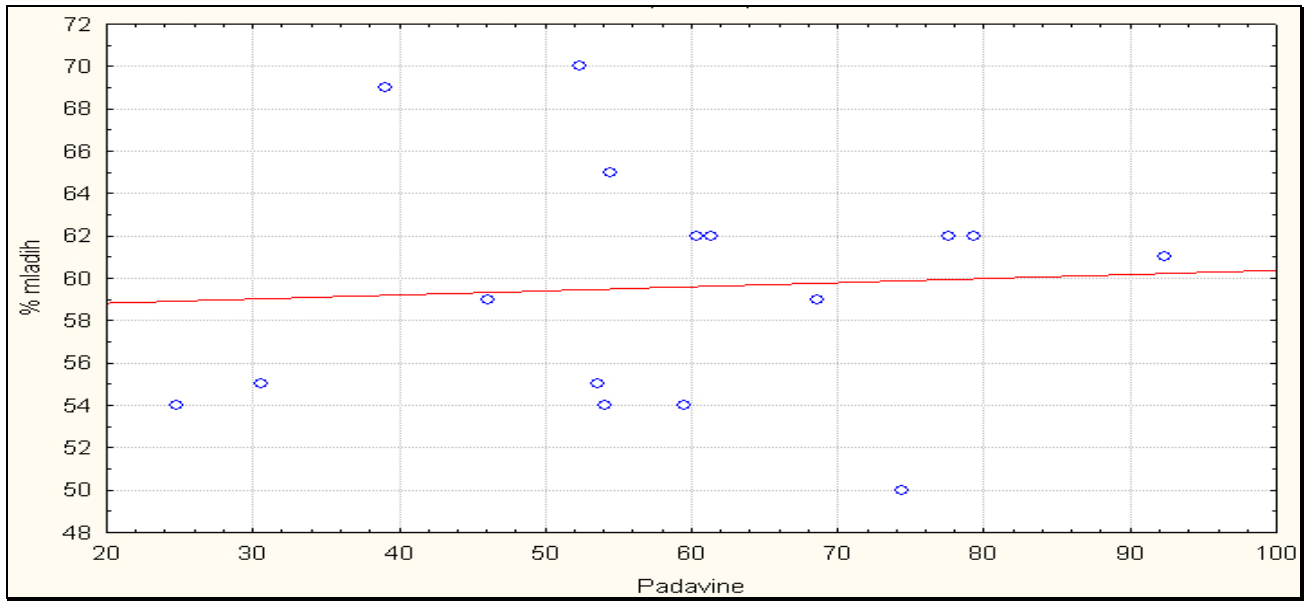

Chart 4. The influence of precipitation on the $\%$ of the young 


\section{CONCLUSION}

On the basis of investigations conducted in the brown hare population of Vojvodina, for the last 16 years, the following conclusions can be made:

- The number of the brown hare population in Vojvodina is stable with an expressive cycle, the average number being 261,216. The largest number was recorded in 1995, and the smallest in 2001.

- The average annual shooting of the brown hare in Vojvodina for the observed period, is 41,115 specimens. The highest shooting was recorded in $1994-65,848$, and the least in $2002-$ 25,753 brown hare.

- The number of the eyes submitted for analysis, during 16 years, was an average yearly 8,346, most was delivered in 2006, least in 1993.

- The average percentage of the young, in the last 16 years, was $60 \%$, which is very good. The worst \% of the young was in the 2006, and the best in 1994.

- Correlation between monthly temperature and $\%$ of the young is small and negative $(r=-0.3846)$.

- There has been found a small negative relationship between monthly temperature in the period of reproduction and \% of the young $(b=-2.3802)$.

- The correlation between the amount of monthly precipitation and $\%$ of the young is small and positive $(r=0.0613)$.
- With increasing the amount of monthly precipitation, $\%$ of the young is slightly higher $(b=0.0193)$.

- Effects of meteorological factors, temperature and precipitation, are not statistically significant for the $\%$ of the young in the population of the brown hare in Vojvodina

- On the basis of all it can be concluded that the number of brown hare population in Vojvodina is stable, and under the control of the huntingground users.

\section{REFERENCES}

[1] Beuković M., Marinković B. (1997.): Uticaj promena u agroekosistemu Vojvodine na brojnost populacije poljske jarebice (Perdix perdix) i zeca (Lepus europaeus).

[2] Jovanović v., Kostić P., Aleksić D. (1971): Prilog proučavanju realnog godišnjeg priraštaja zečeva u Vojvodini i uticaj meteoroloških elemenata na taj priraštaj. Zbornik radova, Simpozijum o lovstvu, Beograd, str. 136-147.

[3] Jovanović V., Aleksić D. (1976): Prilog proučavanju plodnosti zeca u uslovima Vojvodine. Zbornik radova, Simpozijum o lovstvu, Beograd, str. 136-147.

[4] Popović Z., Bogdanović V., Gajić I. (1997): The influence of climatic factors on the participation of young in the hares population (Lepus europaeus Pall). Ekologija, 32 (I) 139-144.

[5] Šelmić V. (1980): Proučavanje zakonomernosti dinamike zeca u Vojvodini i njihova primena u planiranju racionalnog korišćenja (Doktorska disertacija). Sumarski fakultet, Beograd. 